\title{
BFRPロッドによるRC橋脚の耐震補強効果 に関する実験的研究
}

\author{
呉 智深 1 - 林 継恩 2 - 黄 橫 3 - 甲斐 紳也 4 - 井上 康太 4 \\ 1正会員 茨城大学工学部都市システム工学科（テ316-8511茨城県日立市中成沢町4-12-1） \\ E-mail: zhishen.wu.prof@vc.ibaraki.ac.jp \\ 2正会員 大日本コンサルタント（株）インフラ技術研究所（†170-0003 東京都豊島区駒込3-23-1） \\ E-mail:rin_keion@ne-con.co.jp \\ 3学生会員 茨城大学工学部都市システム工学科（テ316-8511茨城県日立市中成沢町4-12-1） \\ E-mail: hhly9527@gmail.com \\ 4学生会員 茨城大学理工学研究科都市システム工学専攻 博士前期課程 \\ （干316-8511茨城県日立市中成沢町4-12-1）E-mail:12nm804t@hcs.ibaraki.ac.jp
}

\begin{abstract}
本研究では, $\mathrm{RC}$ 橋脚の耐震補強における変形性能や復旧性の向上を主な目的とし, RC橋脚表面に掘削 した溝に埋め込む工法（NSM工法）により連続バサルト繊維ロッド（BFRPロッド）を導入した合理的な 耐震構造を提案する.

本論文は, $\mathrm{RC}$ 橋脚において BFRPロッドと埋め込み材, コンクリートとの付着剥離による降伏後の二次 剛性を向上し, 残留変位を低減することで, 変形性能を高め, 復旧性を向上したRC橋脚の補修・補強技 術に関する実験的検討を行った。また，ファイバーモデルによる解析的検証も試みた。 その結果， RC橋 脚において, 環境にやさしく, 耐食性に優れ, かつ高じん性を有するBFRP材を生かした高い耐震補強効 果が期待できる.
\end{abstract}

Key Words : BFRP rods, seismic design, reparability, residual displacement, post-yield stiffness

\section{1.はじめに}

1994年米国Northridge地震や1995年の阪神・淡路大震災 などでは，鉄筋コンクリート橋脚（RC橋脚）に甚大， かつ多種多様な損傷や破壊が発生した ${ }^{122}$. 復旧作業にお いては，大きく損傷した橋脚だけでなく，残留変位が大 きいために, 耐荷力には問題がないものの, 撤去・再構 築となった橋脚も数多く存在した 2,3). これを契機に, 道 路橋示方書4には，1996年の改定以後，橋脚の残留変位 に対する規定が設けられた。

この規定を受けて, 残留変位を低减させるための構造を 開発する研究が行われてきた．池田は， RC橋脚にPC鋼 棒を挿入して緊張力を与える橋脚を提案し, 静的および 疑似動的実験よりその耐震性能を検証している5。．睦好 らも同様な構造に対して載荷実験を行い, 非線形履歴モ デルを提案しているの。 これらの研究の成果は，プレス トレストコンクリート橋脚の耐震設計ガイドラインクと してまとめられている. 堺らはRC 橋脚にアンボンドPC 鋼棒を挿入し，上部構造の死荷重による軸力程度の緊張 力を与えた構造を提案し, 振動台実験により評価してい る8).また，家村らはアンボンド高強度芯材を有する橋
脚（UBRC 橋脚）を提案している9).しかしながら，こ うした構造では, 最適な設計に関する明確な提案は提示 されていない，また，震災後の残留変位の減少を目的と して検討された例も少ない.

近年では, 迅速な復旧性を備えた構造物の耐震補強技 術の中, 連続繊維複合材 (Fiber reinforced polymers; FRP) の接着補強による而震性能向上が期待されているが，耐 震補強のうち, 復旧性や変形制御に関する研究はまだあ まり実施されていないのが現状である.

以上より, 本研究では, $\mathrm{RC}$ 橋脚の残留変位を効果的 に低減する而震構造を開発するために，正負交番載荷実 験によりFRPで補強したRC橋脚の耐震補強効果の検討を 行った. そこで, FRPの一種で, 天然素材から作られる かつ高じん性を有する連続バサルト繊維ロッド（Basalt Fiber Reinforced Polymer Rods; BFRPロッド）をRC橋脚の表 面に埋め込む（Near Surface Mounted; NSM）工法（NSMBFRPR工法と呼ぶ）を適用し，二次剛性の向上，残留変 位の低減，またBFRPロッドと埋め込み材，コンクリー 卜との付着剥離による変形性能を高めたRC橋脚の復旧 性を考慮した補修・補強技術に関する検討を行った，本 論文では，正負交番載荷実験の結果を重点的に報告する. 


\section{NSM-BFRPR工法の基本コンセプト}

現在， $\mathrm{RC}$ 橋脚の而震補強工法として， $\mathrm{RC}$ 巻き立て工 法や鋼板巻き立て工法が多用されている11. しかしなが ら, 前者は, 作業が大掛かりとなり, 施工性の面で補強 工法の適用が限定される場合がある，また，躯体断面が 増加することにより建築の限界や景観に問題となる場合 がある，さらに，躯体自重が増加するため基礎の而打震性 を再検討する必要がある，後者は，躯体断面および重量 の増加が前者と比べて低減されることにより，建築限界 や景観などの問題が少なく，基礎の再検討も一般的には 不要である. しかし，鋼板の搬入や設置などの作業に重 機が必要になり，長期的には腐食などに対する維持管理 上の問題があることが指摘されている10). そこで，炭素 繊維シート（CFS）による巻き立て工法が注目され, 適

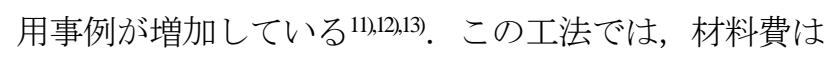
前述工法により多少割り高になるが，CFSの自重が軽い ため, 補強による躯体断面および身区体重量の増加がほと んどない，また施工の際，特殊重機が不要であり，狭い 空間での作業が可能なため施工性に優れている.さらに, CFSは耐食性に優れるため, 補強材料の腐食の問題がな い. しかしながら, CFS 巻き立て工法においては, 接着 界面におけるせん断抵抗の限界が存在するため, FRP シ 一トの高い引張強度が有効に活用されないうちに, 早期 に補強材の剥離が発生することで, 終局耐力の向上効果 に限界がある，さらに，火㷋，衝撃や環境条件など外部 影響を受けやすいと指摘されている14). こうした弱点を 克服寸る目的として, 著者らは, RC橋脚の表面に掘削 した溝に連続バサルト䋊維ロッドを埋め込む補強工法

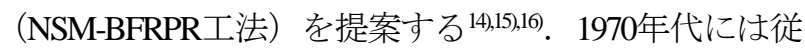
来NSM工法の研究として鉄筋埋め込夕補強の研究に取 り組まれたが，鉄筋は錆びるほか，塩害や中性化による 鉄筋腐食により補強効果が得られなかった17). また, CFRPを用いたNSM補強では, 高い剛性を示し, 変形性 能を抑えることが見込まれるが，CFRPはFRPの中でも 低じん性を有する材料であり, FRP補強構造物が有する じん性向上等の補強効果は期待できない，そのため，本 工法では，耐腐食性に優れるかつ高じん性を有する BFRPを選定した。この工法の概念図を図-1に示寸.

NSM-BFRPR工法では, 構造物に補強棒材であるBFRP口 ッドを直接埋め込むため構造物間の高い付着性能を保持 し，かつ耐熱性に弱いBFRPロッドを火災から保護でき るなどから，FRP補強材の特徴を充分に発揮すると期待 できる.

従来の $\mathrm{RC}$ 橋脚では大地震の際，鉄筋の有する引張強 度だけでは十分な耐力を持たず，鉄笳降伏一と至り大き な残留変位が生じた（図-2）。また，道路橋示方書4)で はRC橋脚の復元力特性を降伏後の二次剛性比が0である

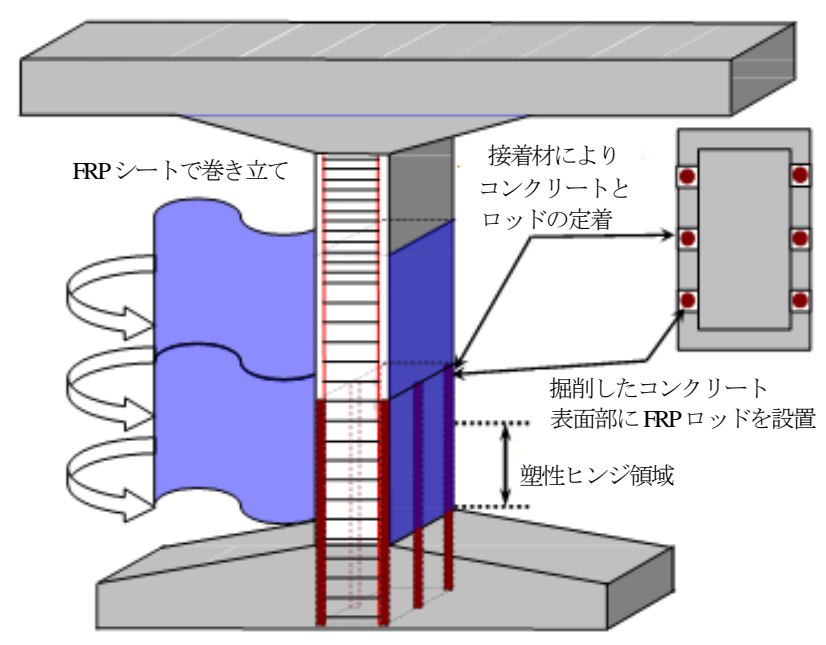

図-1ＦRPロッド埋め込み工法概念図

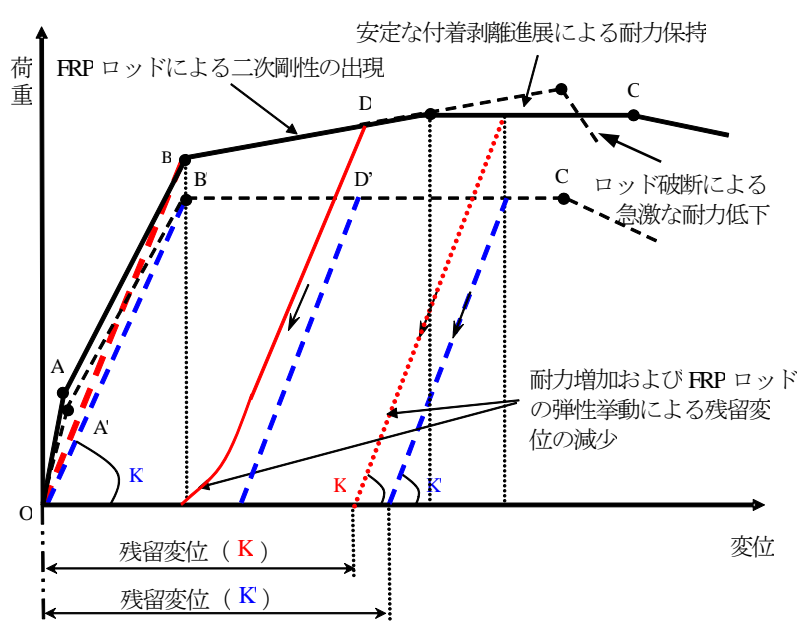

図-2 FRPロッド補強橋脚の荷重-変位関係の概念図

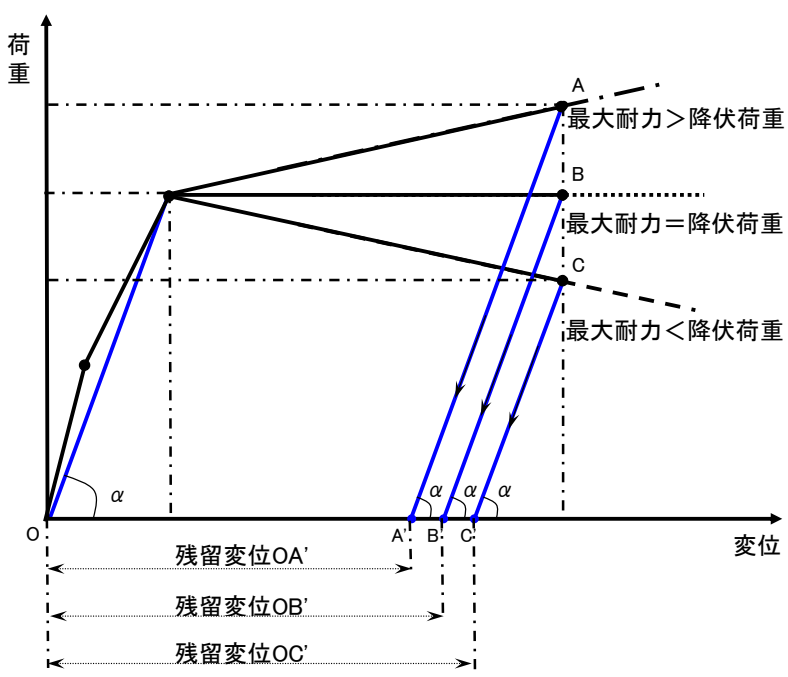

図-3 鉄筋降伏後の二次剛性が残留変位に及ぼす影響

完全弾塑性型にモデル化されている，そこに弾性部材で あるBFRPロッドを導入することで二次剛性を有する構 造を得ることができる．二次剛性の出現により耐力が増 
加し, BFRPロッドの弾性挙動から, 従来のRC構造に比 べ残留変位の低減も期待できる（図-3）。しかし，塑性 化によってじん性を有する鉄筋と違い, BFRPロッドは 弾性部材であるため, 終局時に破断を生じ, 構造物本体 に急激な負荷を及ぼし，耐力に大きな影響を与える.

そこで, 本研究では, BFRPロッドが終局耐力を迎える 前に埋め込み材による安定した付着剥離の進展により, $\mathrm{RC}$ 橋脚の一定の耐力を保持させ，じん性の確保および 残留变位の低減を目的として実験的検討を行った.

\section{BFRPロッドの付着挙動に関する実験的検討}

本研究では, BFRP ロッドと埋込み材の付着性能を評 価するため一軸引抜試験（図-4）を行った，用いた接着 材は, 従来埋込み工法の接着材として用いられている工 ポキシ樹脂およびパテと比べて流動性が高く短期間で強 度を発揮するポリマーセメントの 2 種類を用いた.

\section{（1） 試験体および試験方法}

D6,D10,D12,D14の4つの径を有するロッド（長さ1000 $\mathrm{mm})$ の片側端部に鋼管を取り付けた。 また, 供試体の 材料特性を表-1 に示す．ロッドの表面形状は，制作時に 表面を螺旋状に絞り込んで，全長にロープネジ状を加工 している. ロッドを埋め込んだコンクリートは幅400x奥 行300x高1800mmの寸法で打設し，中心から3等分間隔に

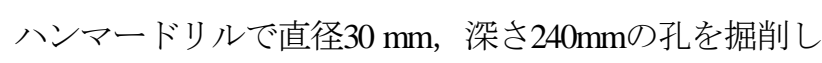
た. 孔部分はエタノールを用いてコンクリート表面に付 着した粉末を除去し, ロッドの埋め込み部分にプライマ 一を塗布した. その後, 接着材にエポキシパテを使用し た試験体（以下， E試験体）は，掘削孔にエポキシパテ を流し込みロッドを埋め込んだ。一方, 接着材にポリマ 一セメントを用いた試験体（以下，P試験体）は，掘削 後プライマーで表面処理をした後, ポリマーセメントを 流し込みロッドを埋め込んだ.また, 試験体は, 油圧ジ ヤッキで一軸引抜試験を行った。

表-1 使用材料

\begin{tabular}{|c|c|c|}
\hline \multicolumn{2}{|c|}{ 材料 } & 詳細 \\
\hline \multirow{4}{*}{$\begin{array}{c}\text { BFRP } \\
\text { ロッ } \\
\text { ド }\end{array}$} & $\begin{array}{c}\mathrm{BD} \\
6\end{array}$ & $\begin{array}{l}\text { 直径 : } 6 \mathrm{~mm}, \text { 付着面積 : } 4580.4 \mathrm{~mm}^{2} \\
\text { 引張強度 : } 1030 \mathrm{MPa} \text {, 弾性係数 : } 51 \mathrm{GPa}\end{array}$ \\
\hline & $\begin{array}{c}\mathrm{BD} \\
10\end{array}$ & $\begin{array}{l}\text { 直径 : } 10 \mathrm{~mm} \text {, 付着面積 : } 7696.9 \mathrm{~mm}^{2} \\
\text { 引張強度 : } 1030(\mathrm{MPa} \text {, 弾性倸数 : } 51 \mathrm{GPa}\end{array}$ \\
\hline & $\begin{array}{l}\mathrm{BD} \\
12\end{array}$ & $\begin{array}{c}\text { 直径: } 12 \mathrm{~mm} \text {, 付着面積: } 9274.0 \mathrm{~mm}^{2} \\
\text { 引張強度 : } 1030 \mathrm{MPa} \text { ，弾性係数 : } 51 \mathrm{GPa}\end{array}$ \\
\hline & $\begin{array}{l}\mathrm{BD} \\
14\end{array}$ & $\begin{array}{c}\text { 直径: }: 14 \mathrm{~mm}, \text { 付着面積 : } 10863.6 \mathrm{~mm}^{2} \\
\text { 引張強度 : } 1030 \mathrm{MPa} \text {, 弹性係数 : } 51 \mathrm{GPa}\end{array}$ \\
\hline \multirow{2}{*}{$\begin{array}{l}\text { 接着 } \\
\text { 剂 }\end{array}$} & $\mathrm{E}$ & 引張強度 : $51.9 \mathrm{MPa}$ ，弾性係数 : $3.43 \mathrm{GPa}$ \\
\hline & $\mathrm{P}$ & 圧縮強度 : $30.4 \mathrm{MPa}$ ，曲げ強度 : $7.3 \mathrm{MPa}$ \\
\hline
\end{tabular}

*E : エポキシパテ，P：ポリマーセメント.

\section{（2）付着性能評価}

埋め込み材にエポキシパテを用いた $\mathrm{E}$ 試験体の破壊形 式は，E-D6でロッドの破断，E-D10でロッドの一部が破 断して引き抜け， E-D12， E-D14で引き抜けが生じた. ここに，E-D6 はロッドの補強効果が表れる以前にロッ ドの破断が先行したと考えられる.また， E 試験体では， 表面のコンクリートを巻き上げて引き抜けが生じた. こ れはロッドが破断したあと，エポキシパテとコンクリー 卜の付着強度が高いため, エポキシパテに表層のコンク リートが大きく付いた形での破壊によるものと考えられ る. 一方で, $\mathrm{P}$ 試験体は, 全ての試験体でロッドとセメ ント間で引き抜けが生じた。 また，D12 試験体の荷重一 すべり量の関係を図-5に示す.エポキシパテ接着試験は 高荷重で引き抜けが生じ, 引き抜け後に急激な荷重低下 を示した. 一方, ポリマーセメントは, パテと比べて低 荷重で引き抜けが生じ，引き抜け後に緩やかな荷重低下 を示した。

最大軸応力 $\sigma_{\text {max }}$ とロッド径および最大付着応力 $\tau_{\text {max }}$ とロッド径の関係をそれぞれ図-6, 図-7 に示す。また, 最大軸応力および最大付着応力は式(1)，(2)でそれぞれ 評価する.

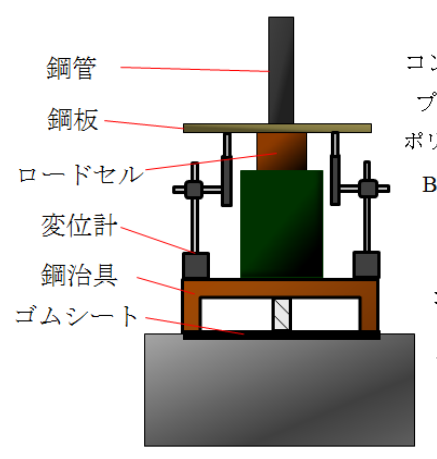

(a) ポリマーセメント

図-4 引き抜き試験の概要

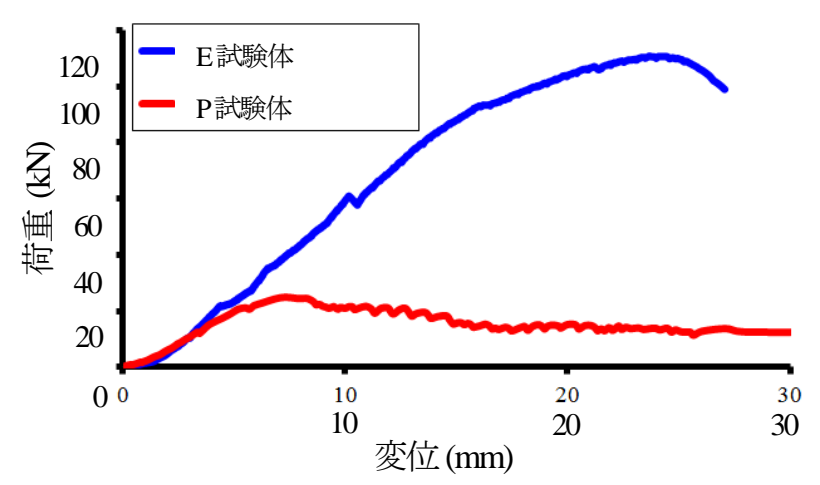

図-5 コンクリート埋込み引抜試験の結果(D12) 


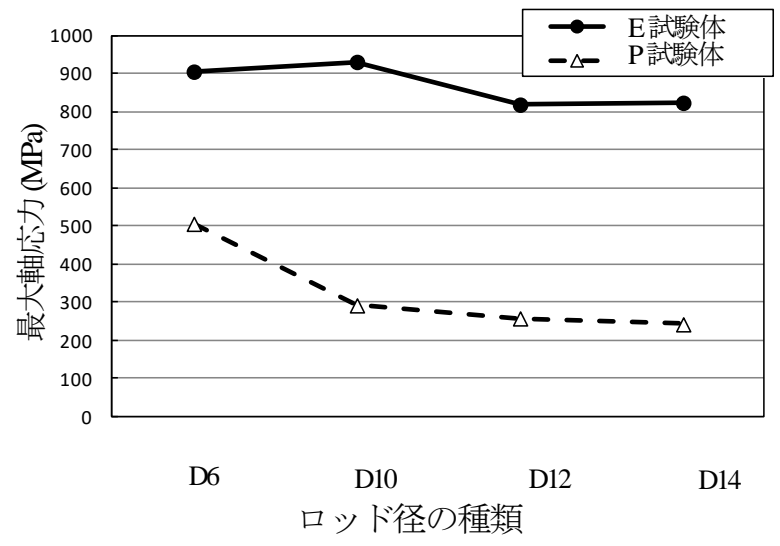

図-6 ロッド径と応力の関係

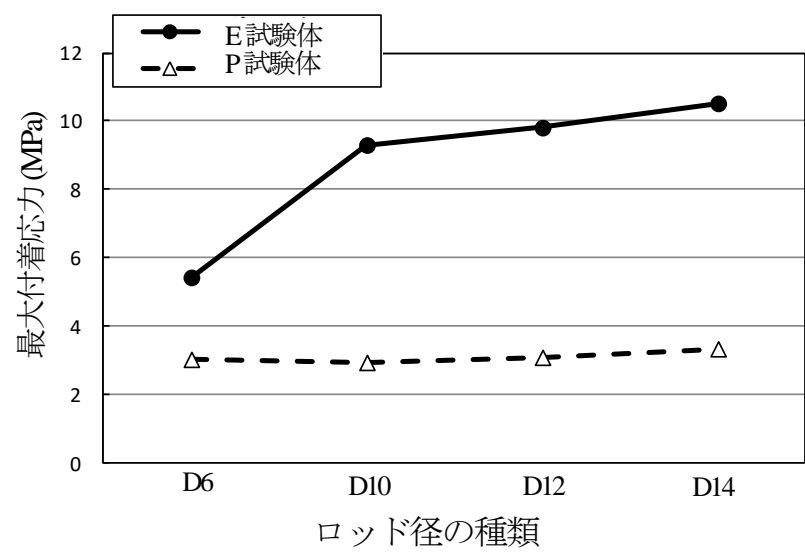

図-7 ロッド径と応力の関係

$$
\begin{gathered}
\sigma_{\text {max }}=\frac{P_{\text {max }}}{(D / 2)^{2} \pi} \\
\tau_{\text {max }}=\frac{P_{\text {max }}}{D L \pi}
\end{gathered}
$$

ここに,

$$
\begin{aligned}
& \mathrm{P}_{\max } \text { ：最大荷重 }(\mathrm{kN}) \\
& \mathrm{D} \quad \text { : ロッド径 }(\mathrm{mm}) \\
& \mathrm{L} \quad \text { : ロッドの埋込み深さ }(\mathrm{mm})
\end{aligned}
$$

$\mathrm{E}$ 試験体および $\mathrm{P}$ 試験体の両試験体において，ロッド 径 $\mathrm{D}$ の増大により, 最大荷重は増加し, 最大軸応力は減 少する傾向を示した. 一方, 最大付着応力は, 引き抜け が生じた E試験体およびP試験体でそれぞれ 13\%，7\%以 内で同程度の值を示した.

そのため，本試験で用いたロッド径 6 14 mm では付着 強度が一定とし, 引き抜けが生じた試験体の最大付着応 力の平均值を付着応力 $\tau_{\mathrm{b}}$ として評価する. エポキシパ テおよびポリマーセメントの付着強度は，それぞれ 10.6 $\mathrm{MPa}, 3.0 \mathrm{MPa}$ であり, エポキシパテはポリマーセメント に比べて 3.7 倍の付着強度が得られた。

したがって，従来の接着材であるエポキシパテでは，
本工法で期待する安定した付着剥離を生じるのは難しく 急激な剥離破壊またはロッド破断による脆性破壊が危惧 される.一方，ポリマーセメントは，エポキシパテと比 べて高いじん性を示すが，付着力が小さく，早期付着破 壊が生じる，そのため，本工法では，まずはエポキシパ テを溝の半分程度まで入れ，その後BFRPロッドを挟む ようにポリマーセメントで定着させる（概念図は図-9）。 このように両者を併用することで高付着力かつ高じん性 を備えた接着工法を提案する.

\section{（3）ロッド径と付着性能}

付着破壊を生じる際のロッドの軸応力 $\sigma_{f}$ を式(3)とし て評価すると， $\sigma_{f}$ がロッドの破断応力 $1030 \mathrm{MPa}$ を示す ロッド径（以下，繊維径と称す） を境として破壊形式 が異なると考えられる.

$$
\sigma_{f}=\frac{4 L}{D} \tau_{b}
$$

ここに,

$$
\begin{aligned}
& \mathrm{L} \quad \text { : ロッドの埋込み深さ }(\mathrm{mm}) \\
& \tau_{\mathrm{b}}: \text { 付着強度 }\left(\mathrm{kN} / \mathrm{mm}^{2}\right) \\
& \mathrm{D} \quad: \text { ロッド径 }(\mathrm{mm})
\end{aligned}
$$

エポキシパテおよびポリマーセメントの繊維径は，そ れぞれ $9.5 \mathrm{~mm}, 2.9 \mathrm{~mm} ゙$ あった。 繊維径付近のロッド径 では，ロッドの破断と引き抜けの両破壊形式を示し，口 ッド径Dが䋊維径より小さい場合，ロッドの破壊が先行 する，一方䋊維径より大きなロッド径では，付着破壞が 生じると考えられる．また，付着破壊を示寸場合は，口 ッド径が増大するとロッドの軸応力は低い段階で付着破 壊を示す. 従って, BFRPロッドの強度を十分に発揮し, かつ破断以前に引き抜けが生じる最適なロッド径はD12, D14であると考えられる.

\section{NSM-BFRPR橋脚の正負交番実験の供試体概要}

著者らの既往研究144,15)を踏まえ，供試体は，現行の耐 震設計基準に基づく構造を想定した曲げ破壊型 $\mathrm{RC1}$ シリ 一ズと，阪神大震災以前の耐震設計基準に基づく構造を 想定した曲げせん断破壊型RC2 シリーズの2 種類を選定 した．また，コンクリートと鉄筋の材料特性を表-2 に， 供試体の諸元や配筋要領を表-3および図-8 にそれぞれ示 す.

表-2 材料特性

\begin{tabular}{|c|c|}
\hline 材料 & 詳細 \\
\hline コンクリート & 圧縮強度 $: 30 \mathrm{MPa}$ \\
& 弾性係数 $: 28 \mathrm{GPa}$ \\
\hline 軸方向鉄筋 & 引張強度 $: 540.7 \mathrm{MPa}$, 降伏強度 : \\
$(\mathrm{SD} 345 \mathrm{D} 13)$ & $348.9 \mathrm{MPa}$, 弾性係数 $: 202 \mathrm{GPa}$ \\
\hline
\end{tabular}


表-3 供試体の諸元

\begin{tabular}{|c|c|c|c|c|c|}
\hline 供試体名 & $\begin{array}{c}\text { 軸応力 } \\
(\mathrm{MPa})\end{array}$ & 帯鉄筋 & 軸方向鉄筋 & BFRPロッド & 備考 \\
\hline $\mathrm{RC} 1$ & 1 & D6@ @50 & $6 \times \mathrm{D} 13$ & 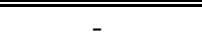 & 無補強 \\
\hline RC1' & 1 & D6@50 & $6 \times \mathrm{D} 13$ & - & 無補強（塑性域まで破壊） \\
\hline RC1'-RE1-B1 & 1 & D6@50 & $6 \times \mathrm{D} 13$ & $4 \times$ D6 & 修復＋補強（1回目） \\
\hline RC1'-RE2-B1 & 1 & D6@50 & $6 \times \mathrm{D} 13$ & $4 \times$ D6 & 修復＋補強（2回目） \\
\hline RC1-N-B1 & 1 & D6@50 & $6 \times \mathrm{D} 13$ & $4 \times$ D6 & ウエットボンディング \\
\hline $\mathrm{RC} 2$ & 1 & D6@100 & $6 \times \mathrm{D} 13$ & - & 無補強 \\
\hline RC2-D6-E & 1 & D6@100 & $6 \times \mathrm{D} 13$ & $4 \times$ D6 & パテによる全面接着 \\
\hline RC2-D6-E' & 1 & D6@100 & $6 \times \mathrm{D} 13$ & $4 \times$ D6 & パテによる部分接着 \\
\hline RC2-D6-EP & 1 & D6@100 & $6 \times \mathrm{D} 13$ & $4 \times \mathrm{D} 6$ & パテ＋セメント+巻き立て \\
\hline RC2-D10-E & 1 & D6@100 & $6 \times \mathrm{D} 13$ & $2 \times \mathrm{D} 10$ & パテ＋巻き立て \\
\hline RC2-D10-EP & 1 & D6@100 & $6 \times \mathrm{D} 13$ & $2 \times \mathrm{D} 10$ & パテ+セメント＋巻き立て \\
\hline RC2-D12-E & 1 & D6@100 & $6 \times \mathrm{D} 13$ & $2 \times \mathrm{D} 12$ & パテ+巻き立て \\
\hline RC2-D12-EP & 1 & D6@100 & $6 \times \mathrm{D} 13$ & $2 \times \mathrm{D} 12$ & パテ＋セメント＋巻き立て \\
\hline RC2-D14-E & 1 & D6@100 & $6 \times \mathrm{D} 13$ & $2 \times \mathrm{D} 14$ & パテ+巻き立て \\
\hline RC2-D14-EP & 1 & D6@100 & $6 \times \mathrm{D} 13$ & $2 \times \mathrm{D} 14$ & パテ＋セメント＋巻き立て \\
\hline
\end{tabular}
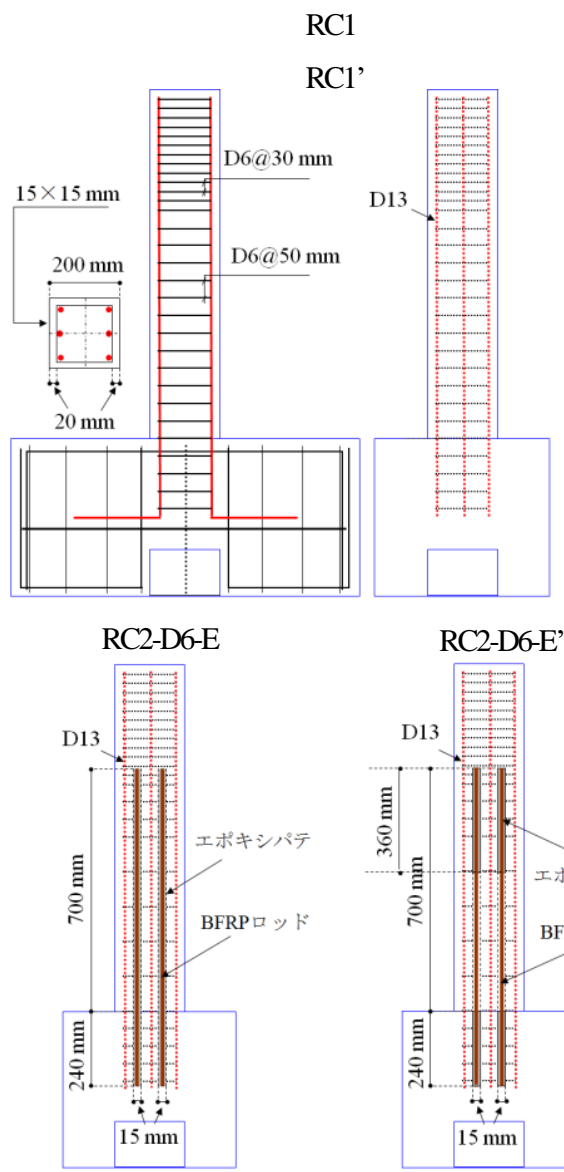

(1) 曲げ破壊型RC1シリーズ

現行の而震設計基準に基づいた構造物を想定したRC1 シリーズでは，損傷後の復旧性および，新設時の補強効 果についての検討を行う.

無補強の供試体RC1 での最終変形7 $8 y$ 「第4. (3)節で後 述する軸方向鉄筋の降伏変位 $\delta y($ 約 $8.5 \mathrm{~mm})$ の7倍, 寸

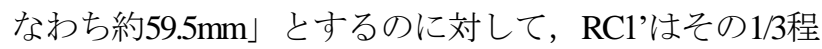

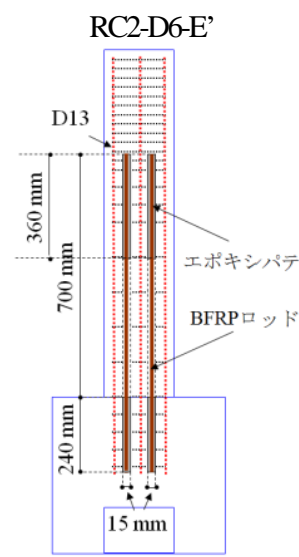

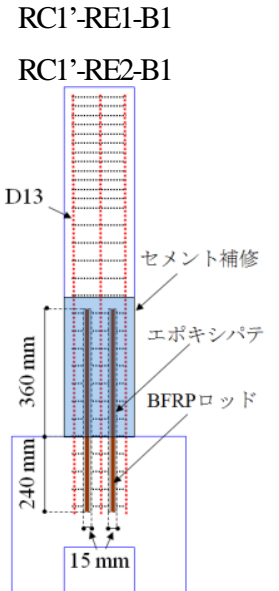
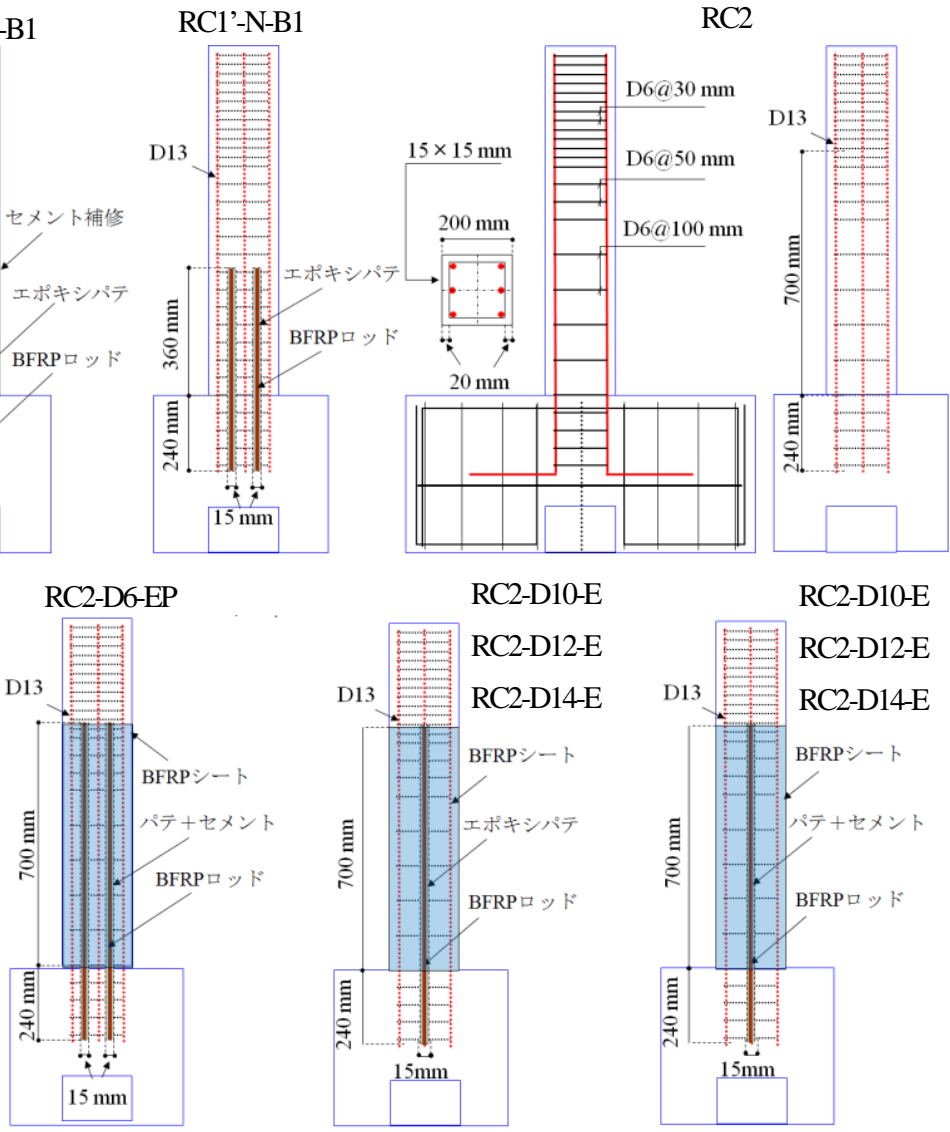

図-8 供試体の概要図

度，すなわち降伏変位2.58y（約21.25mm）まで繰り返し 載荷まで損傷を与えた後，ひび割れの進行したかぶり部 のコンクリートを除去し，ポリマーセメントで補修を施 し，さらにBFRPロッド埋め込み工法を適用した柱が RC1'-RE1-B1 である. また，RC1'-RE1-B1を試験した後, コンクリートのかぶり部を除去し再度，ポリマーセメン トとBFRPロッドの埋め込み工法により補修・補強した 
ものがRCl'-RE2-B1 である. 埋め込み材にはそれぞれエ ポキシパテを用いる.

また，新設構造物を想定し，コンクリート打設時にあ らかじめBFRP ロッドを埋設させたものがRC1-N-B1 であ る。これは，FRPとコンクリート間の付着を確保するた めに, 湿潤面への接着を可能にするウェットボンディン グを用いる．ウェットボンディングとは，FRPの表面に 事前にエポキシパテを塗布したうえで硬化前にフレッシ ユコンクリートを打設する技術である.

\section{（2）曲げせん断破壊型RC2シリーズ}

阪神大震災以前に建設され，現在も供用している曲げ せん断破壊型の構造物を想定するRC2 シリーズに対して 埋め込み工法による補強効果の検討を行う。 そのなか,

RC2-D6-E はエポキシパテによる全面接着(以下，E接着) を行う。また， RC2-D6-E’ は付着長の低減により付着力 の低下を期待し設定する.

RC2-D10-E，RC2-D12-E，RC2-D14-EはBFRPロッドをE 接着で埋設した後, ロッドの外側に帯鉄筋配置工法のか わりにBFRPシート巻き立て工法を行う。これはせん断 補強とBFRP ロッドがエポキシパテとポリマーセメント の界面で剥離した場合にポリマーセメントのひび割れに より BFRP ロッドの飛び出しを防ぎ，耐力低下を遅延す る役割を期待して行ったものである. さらに，RC2-D10EP, RC2-D12-EP, RC2-D14-EPでは, 安定した付着剥離 の進展を期待し，エポキシパテおよびポリマーセメント を併用接着する（図-9）。ここに付着強度の高いエポキ シパテと，付着強度の低いポリマーセメントを併用する ことで，ロッドを破断させることなく，接着材の付着破 壊を促すために併用接着とした．BFRPロッドを溝の半 分までエポキシパテで接着した後，BFRPロッドを挟む ようにポリマーセメントで定着する（以下，EP接着）。 さらにBFRPロッドの定着後, BFRP シートの巻き立て工 法を行う，BFRPシートの巻き立てにより，BFRPロッド の飛び出しを抑制することで，エポキシパテとポリマー セメントで定着させ， ロッド界面での付着剥離を生じ させる目的とする.

\section{（3）正負交番載荷実験}

実験方法は, 図-10 に示すように，構造部材の非線形 域の破壊挙動を含む挙動特性を把握するための一般的な 実験方法とされる静的正負交番載荷試験(18)採用寸る. 載荷方法は，軸方向鉄筋の降伏変位（約 $8.5 \mathrm{~mm} ） を$ 值としてその整数倍で3回繰り返し載荷方法（図-11）で あり，油圧ジャッキによる変位制御載荷を行う。軸力は， 既設RC橋脚構造物が上部構造から受ける死荷重に相当 する1MPaを常時載荷する. 終局は最大荷重を迎えた後, 最大荷重の $80 \%$ 以下となった時点とする.

\section{5. 曲げ破壊型RC1シリーズの実験結果}

\section{(1) $\mathrm{P}-\delta$ 履歴特性}

各供試体の載荷点位置における水平荷重-水平変位関 係（P-8関係）,鉄筋およびBFRPロッドのひずみ分布，残 留変位の関係を図-12に示寸。図-12（a），(b)，(c) は, $\delta$ の計測間隔を $1 / 2 \delta \mathrm{y}$ に, さらに(d) は二次剛性を精度よ く計測するために $1 / 4 \delta y$ にした，載荷点における荷重一 変位関係（図-12 (g)）から，RC1'-RE1-B1およびRCl'RE2-B1は，鉄筋降伏後の二次剛性が確認できる。また, RC1'-RE2-B1は二度の塑性域までの損傷に対しても RC1 と比べ補強効果が確認できる．しかし，RC1-N-B1はRC1 と同程度の挙動を示し, 載荷点変位 $42.5 \mathrm{~mm}$ 時以降に荷 重の低下が見られる.

また，図-12（e），(f) をみると，ひずみ分布より BFRPロッドは性能を発揮しているものの， $\mathrm{RC} 1$ の基部 における鉄筋ひずみの差をみてもほとんど変化がない. これはコンクリートの圧縮強度の違いによるもので, RC1-N-B1の曲げ耐力の理論值が30.40kNに対して最大耐 力36.9kNと確認されることからBFRPによる二次剛性に よる影響であるといえる.

\section{（2）残留変位}

図-12(h)は，各供試体の載荷変位と残留変位を示した ものである．ここでは，各ステップにおいて荷重除荷 時の載荷点変位とする. 補強供試体では, 無補強の供試 体 $\mathrm{RC1}$ と比べて残留変位が低減された。これはRC構造が 除荷に伴いBFRPロッドの弾性挙動が現れたためであると 考えられる.

\section{（3）エネルギ一吸収能}

図-12(i) は供試体の荷重-変位履歴ループの面積より 求めた累積吸収エネルギーのを示したものである，無補 強柱 $\mathrm{RC1}$ と補強柱の両者にほとんど差がみられない.

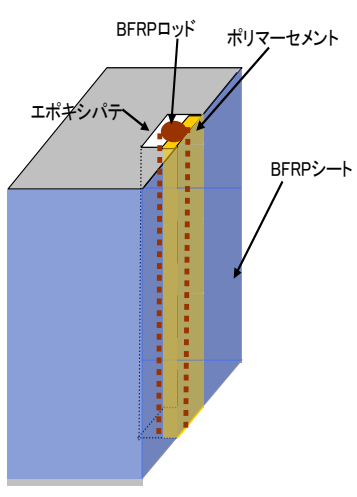

図-9 併用接着の概念図 


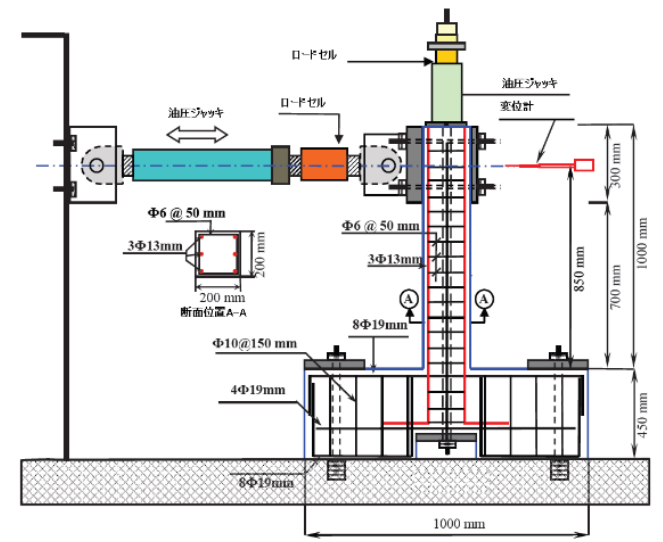

図-10 静的正負交番載荷試験イメージ図

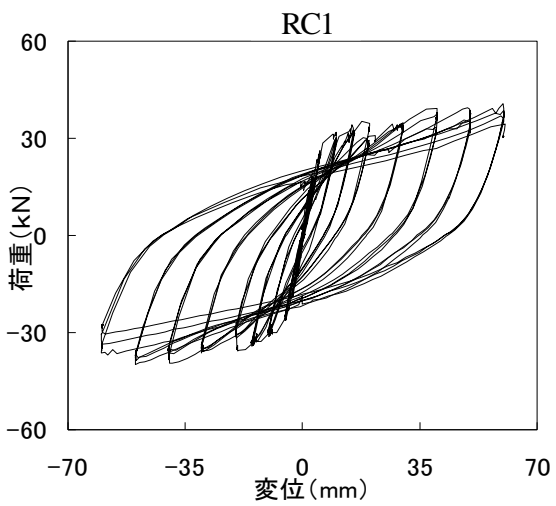

（a）荷重-変位履歴関係

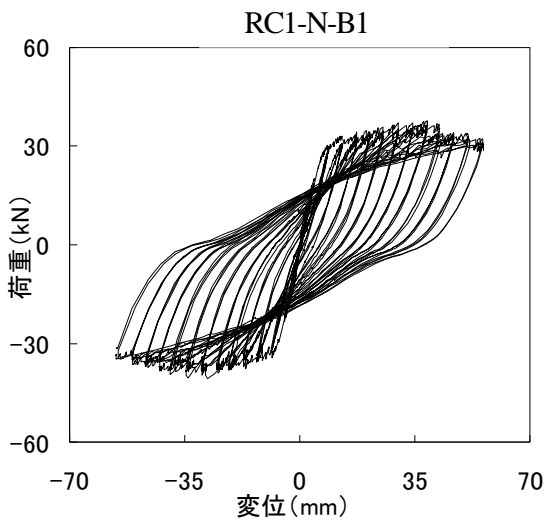

（d）荷重-変位履歴関係

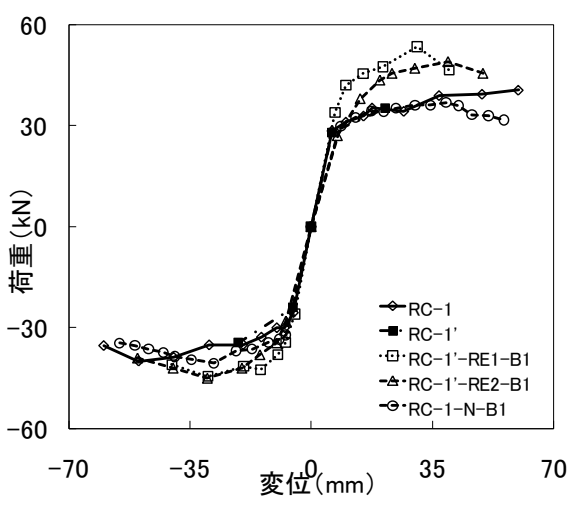

(g) 包絡線

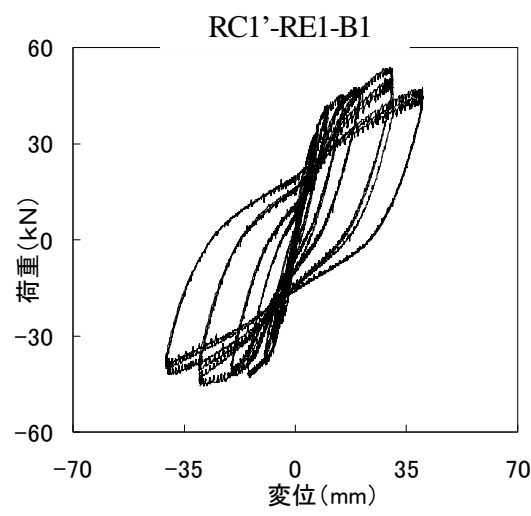

(b) 荷重-変位履歴関係

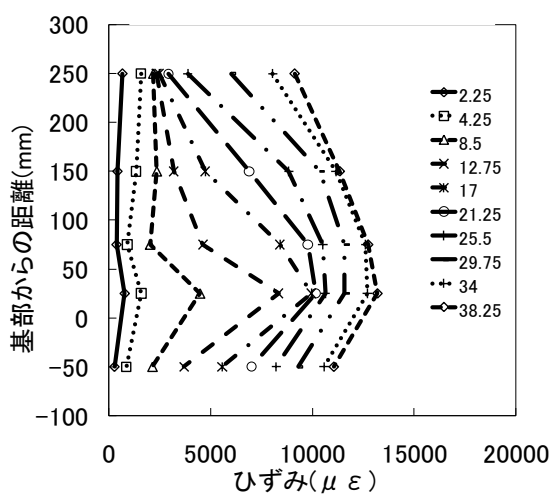

(e) BFRPロッドひずみ

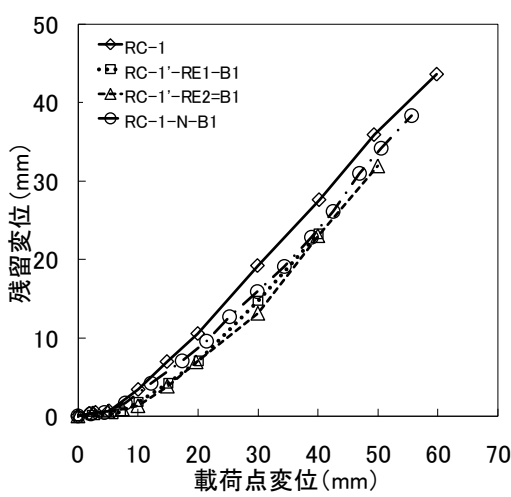

(h) 残留変位と載荷点変位の関係

図-12ＲC1シリーズの実験結果

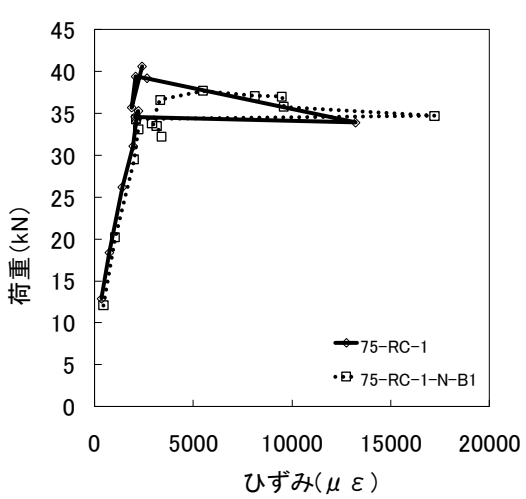

(f) $\mathrm{RC} 1$ と RC1-N-B1 鉄筋ひずみ比較

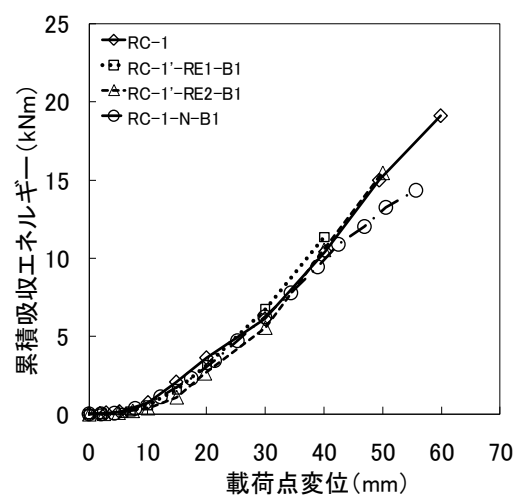

（i）累積吸収エネルギーと載荷点変位の関倸 
以上より, 履歴面積の影響は少なく, 岡性のみを変化さ せたと考えられる。

\section{6. 曲げせん断破壊型RC2シリーズの実験結果}

\section{（1）履歴特性および損傷状況}

供試体の載荷点位置における水平荷重-水平変位関係 (P-8 関係) を図-13 に示す，また，無補強柱試験体 RC2 は水平変位 $21.25 \mathrm{~mm}$ で最大荷重 $36.5 \mathrm{kN}$ を示し, その後, 最大荷重の低下がみられた。これは，せん断破壊による 耐力低下であると考えられる．また，各供試体の破壊形 式は，RC2-D6-E，RC2-D6-E'はともに基部から水平変位 $100 \mathrm{~mm}$ 程度の塑性ヒンジを形成した箇所において BFRP ロッドが破断し, 急激な荷重低下を示した。一方, RC2-D6-EP は基部で BFRPロッドが破断したが，RC2-D6E，RC2-D6-E'に比べ緩やかな荷重低下を示した。

RC2-D12-E の正側では，載荷点変位 $59.5 \mathrm{~mm}$ で付着切
れが生じた，一方，負側では，載荷点変位 $38.25 \mathrm{~mm} に お$ いて柱側面部からロッドが飛び出し，21\%の耐力低下を 示した. その飛び出しは供試体の引張側で進行するひび 割れにより，コンクリートとエポキシパテ・コンクリー トとポリマーセメントの付着が切れ, 引張り発生時に埋 め込んだ供試体側部からロッドが飛び出すものである.

よって, 引張に対してコンクリートとエポキシパテ・ポ リマーセメントとの付着剥離により, ロッドの性能を発 揮できない状況となる，それに対して，RC2-D12-EP の 正側では, 急激な耐力低下が現れずに終局を向かえた. 一方, 負側では, 載荷点水平変位 $20 \mathrm{~mm}$ において柱側面 部からロッドが飛びだし，19\%の耐力低下を示した。 ま た，RC2-D14-Eの正側では，載荷点変位 $21.25 \mathrm{~mm}$ におい て柱側面部からロッドが飛び出し，27.6\%荷重低下を示 し, 試験終了時は, 正負両側で, 鉄筋が座屈した。 RC2-D14-EP では，正負両側で安定した付着すべりを示 し,試験終了時は負側で鉄筋が座屈した。

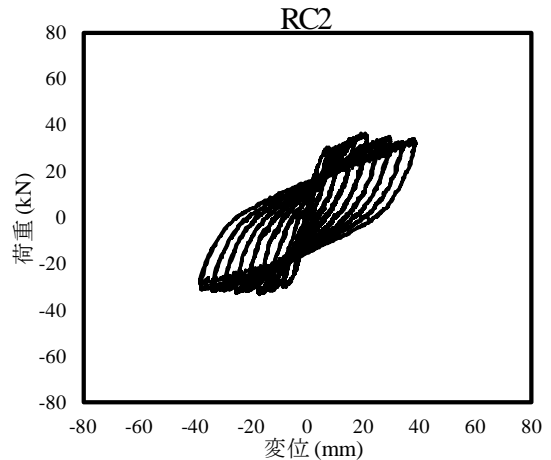

(a) 荷重一変位履歴関係

RC2-D6-EP

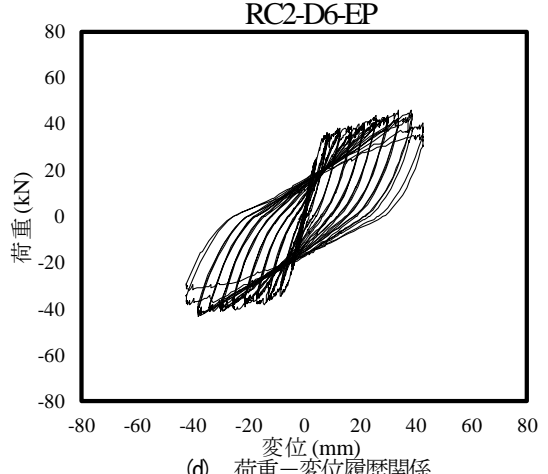

(d) 荷重一変位復歴関係

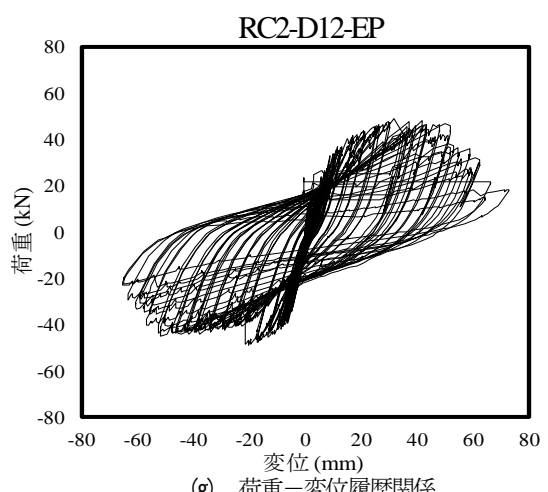

(g) 荷重一変位履歴関倸

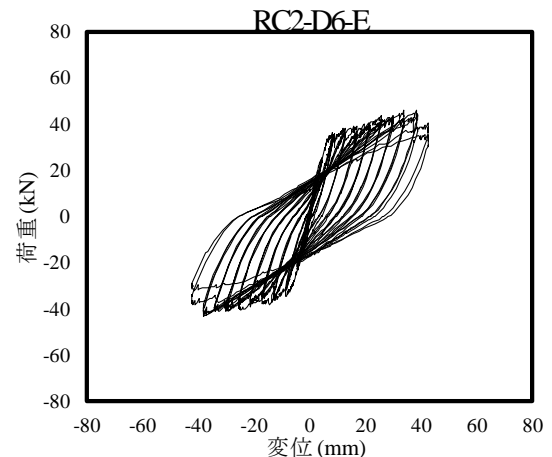

(b) 荷重一変位履歴関係

RC2-D10-E

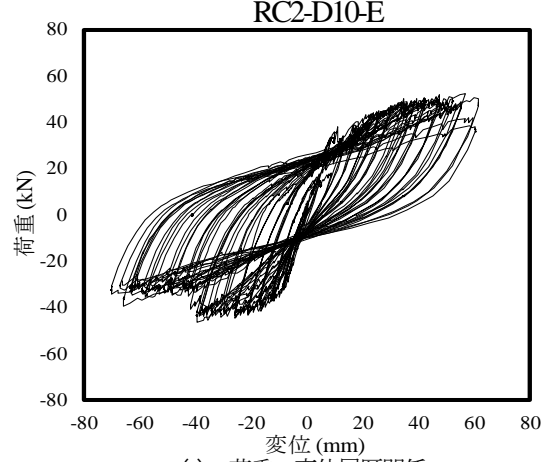

（e）荷重一変位履歴関係

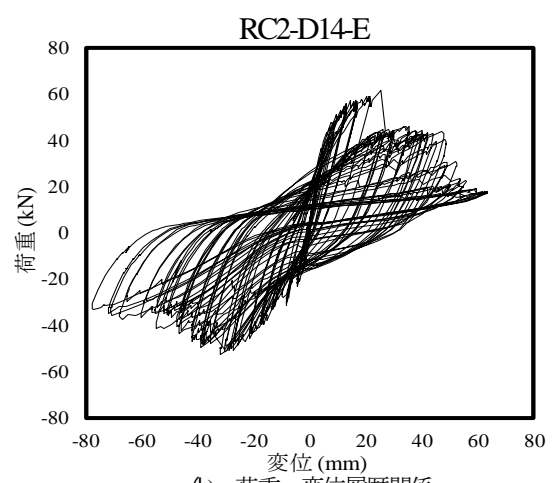

(h) 荷重一変位复歴関倸

図-13 RC2シリーズの実験結果

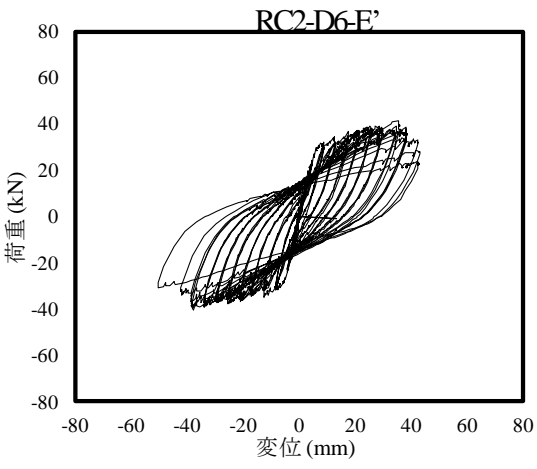

(c) 荷重一変位履歴関倸 RC2-D12-E

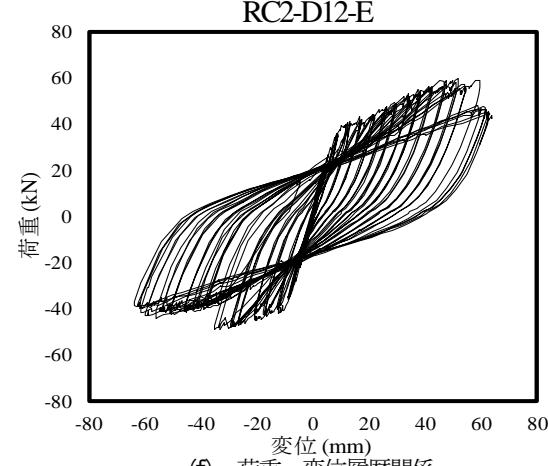

（f） 荷重一変位履歴関係

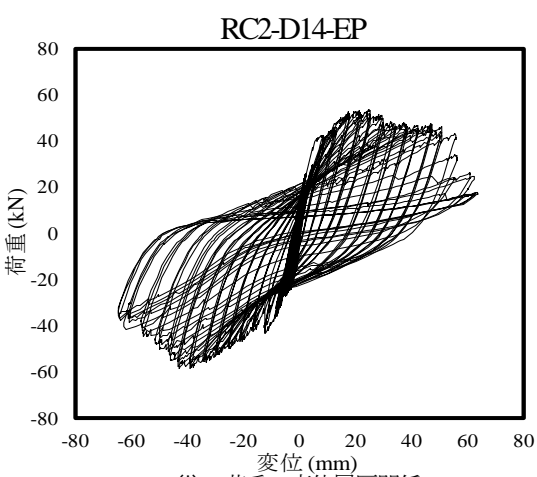

(i) 荷重一変位履歴関係 
埋込み材による補強効果の差異として, RC2-D12-E, RC2-D14Eでは，ロッド抜出しにより急激な耐力低下を 示し，一方，RC2-D12-EP，RC2-D14-EPでは，E接着試験 体と比べて，先にロッドとポリマーセメント間の付着が 切れ，その後，緩やかな荷重低下を示した。 そこで RC2-D12-E，RC2-D12-EP を比較すると，両実験の負側で それぞれ載荷点の水平変位が $38.25 \mathrm{~mm}, 20 \mathrm{~mm}$ で柱側面 部からロッドの抜出しが生じた. これは, ポリマーセメ ントは, エポキシパテと比べて付着強度および材料強度 が低いため, ポリマーセメントが先行して破壊したこと により，エポキシパテとコンクリートの接着面積が小さ い RC2-D12-EP 実験体で先に付着切れが生じてロッドが 抜出したと考えられる.

ロッド径による補強効果の差異として，D12-E，D14-E を比較すると, 両実験体で, それぞれ載荷点の水平変位 が $38.25 \mathrm{~mm} ， 21.25 \mathrm{~mm}$ でそれぞれロッドの抜出しが生じ た.これは, 前章で示した通り, ロッド径が大きくなる ことで，低応力で付着破壊が生じるため， RC2-D14-E で 先にロッドの抜出しが生じたと考えられる。 また，

RC2-D12-EP，D14-EP においても同様に RC2-D14-EP で先 に付着切れを生じたことにより，付着すべりによる荷重 低下を示したと考えられる.

\section{（2）じん性の評価}

じん性の結果を図-14 に示す，本実験では，供試体の じん性を最大荷重を迎えた後の最大荷重の $80 \%$ 荷重を 示した時点の変形を鉄筋降伏時の変形で除した值として 式(4)によりそれぞれ正負の平均で評価した.

ロッド径 6 mm の BFRPロッドで補強した RC2-D6-Eお よびRC2-D6-EPでは，無補強供試体 RC2 と同等のじん性 を示した。 これは, 補強ロッド径が小さいため, BFRP ロッドの補強効果が表れる以前にロッドの破断が先行し たためである，RC2-D10-E， RC2-D12-E，RC2-D14-E のE 接着供試体では, ロッド径の増大でじん性は低下傾向を 示した.これは，ロッド径が大きくなるにつれて引き抜 けが早い段階で生じるためである，また， RC2-D10-EP， RC2-D14-EP の EP 接着供試体では, ポリマーセメントと BFRP ロッド間の付着切れが生じ, ロッドの応力を低減 したため同補強ロッド径の E接着供試体と比べて高いじ ん性を発揮した.

また，RC2-D12-EP は，早期に柱側面部からロッドが 飛び出したことにより, 低いじん性を示した。これは, ポリマーセメントの付着切れにより，BFRP ロッドと柱 部の付着面積が減少したため, ロッドの飛び出しが生じ たものであると考えられる.

$$
\mu=\frac{\delta_{u}}{\delta_{y}}
$$

ここに,
$\delta_{\mathrm{y}}:$ 鉄筋降伏時の載荷点水平変位
$\delta_{\mathrm{u}}:$ 最大荷重 8 割を示した時点の載荷点水平変位

\section{（3）二次剛性の評価}

二次剛性の結果を図-15に示寸，二次剛性 $k_{2}$ とは，鉄筋 降伏後の構造物の剛性を示寸ものであり, 本実験では, 二次剛性 $k_{2}$ を鉄筋降伏時と最大荷重時の傾きとして式(5) によりそれぞれ正負の平均で評価した。また，計算值は， BFRPロッドと柱間の付着を考慮せず，応力ブロックを 用いた断面計算により算出した值である ${ }^{19}$.

BFRPロッドは鉄筋の1/4倍程度の低弾性を有する材料 であり，鉄筋降伏後，BFRPロッドが応力を負担するた め構造物に二次剛性が出現すると考えられる. 本実験で は，無補強橋脚RC2に比べて本工法を適用した全て供試 体で高い二次剛性が発現した。二次剛性は補強ロッド径 の増大で高い効果を発揮したため, 最大荷重も増加傾向 を示した。 また, EP接着供試体では, ポリマーセメン トの付着すべりが早く生じたため, 二次剛性がE実験体 と比べて二次剛性が減少したと考えられる.

$$
k_{2}=\frac{P_{m}-P_{y}}{\delta_{m}-\delta_{y}}
$$

ここに,
$\mathrm{P}_{\mathrm{y}}$ : 断面計算で算出した降伏荷重 $(\mathrm{kN})$
$\mathrm{P}_{\mathrm{m}}$ : 最大荷重 $(\mathrm{kN})$
$\delta_{\mathrm{y}}:$ 鉄筋降伏時の水平変位 $(\mathrm{mm})$
$\delta_{\mathrm{m}}:$ 最大荷重時の水平変位 $(\mathrm{mm})$

\section{（4）残留傾斜角}

載荷時の傾斜角と残留傾斜角の関係を図-16 および図17 にそれぞれ示す，載荷時の傾斜角 $\Delta / \mathrm{H}$ は，載荷変位 ムを橋脚高さ $\mathrm{H}$ で除した值で評価した.

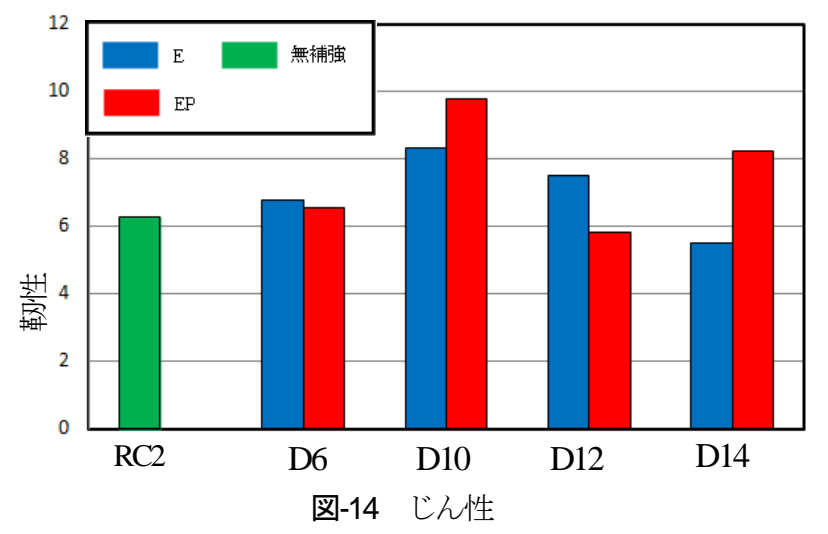



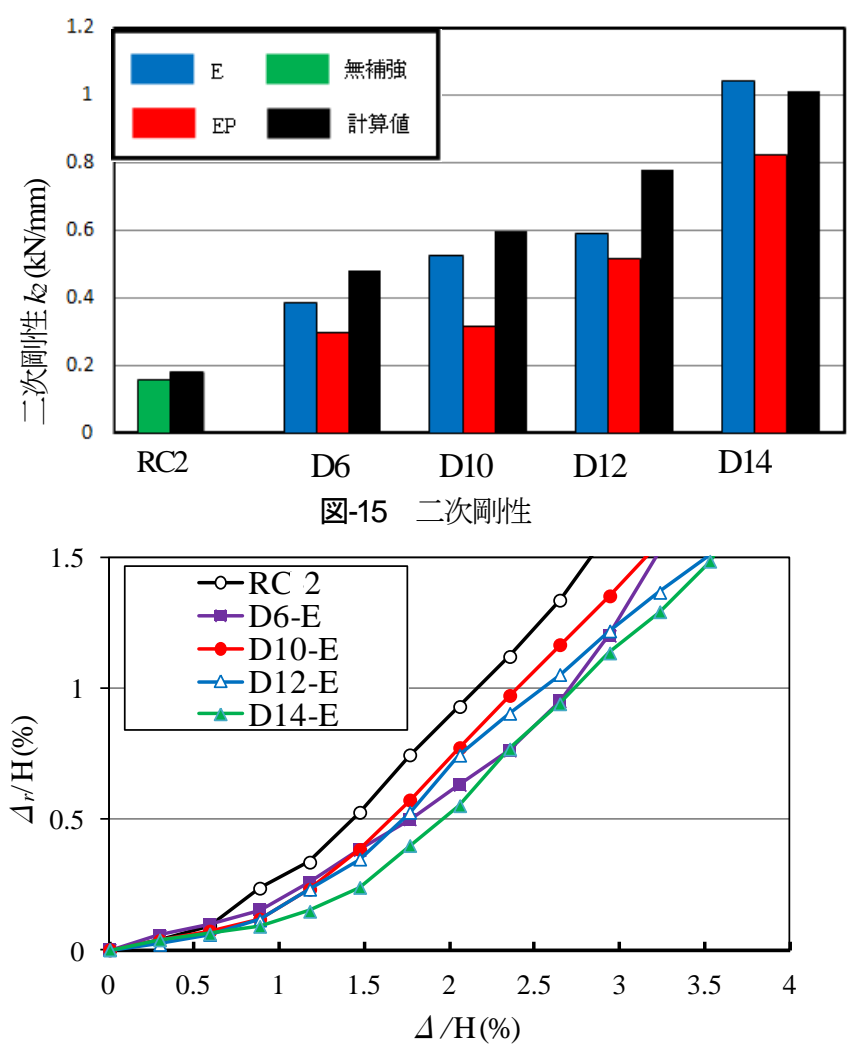

図-16 残留傾斜角 (E接着)

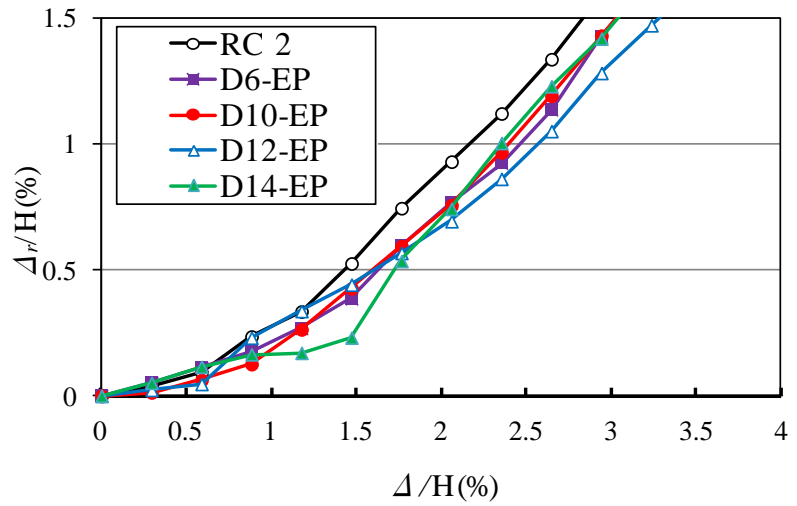

図-17 残留傾斜角 (EP接着)

また, 残留傾斜角 $\Delta_{r} / \mathrm{H}$ は, 残留変位 $\Delta_{r}$ を橋脚高さ $\mathrm{H}$ で除した值で評価した．阪神・淡路大震災では，橋脚 天端の残留傾斜角が $1 / 60$ を橋脚の撤去および再構築の目 安となった. 現在では, 残留傾斜角 $1 \%$ を許容残留傾斜 角と定義されている ${ }^{4}$ ．本工法による補強橋脚は，無補 強橋脚に比べて, 許容残留傾斜範 囲内において E, EP 接着供試体でそれぞれ最大 $26 \% ， 18 \% の$ 残留変位の減少 を示した. これは，供試体に二次剛性が出現したことに より最大荷重が増加したことで，残留変位が低減したと 考えられる.さらに BFRP ロッドは低弾性補強棒材であ るため, 蓄積した応力が除荷されたことで残留変位低減 につながったと考えられる.

接着工法の差異として，E接着供試体 RC2-D6-E，RC2D10-E，RC2-D12-E では，ロッド径の増大に伴い，高い 残留変位の低減効果を示したが，D14-E では，早期付着
切れのため許容残留傾斜角内の変形性能が低減した。 そ れは，補強ロッドによる効果が十分に発揮する以前の段 階でロッドと接着材間で付着剥離が生じてしまうと，そ れ以上の補強効果がえられなくなることが示唆される.

\section{7. ファイバーモデルによる性能再現解析の検討}

本章では, NSM-BFRP工法の解析的評価について示す. 本論文では, 非線形構造解析手法によるファイバー解析 モデルを用いている.

\section{(1) 解析概要}

ファイバー解析モデルは, 梁理論に基づくフレーム解 析の手法である。その原理は，断面を微小要素に分割し， 内力と外力のつり合い式から断面のひずみ分布を求め, 断面剛性を算定するものである. このとき，断面内のひ ずみ分布を直線分布と仮定し，微小要素ごとの応力度は, 各微小要素のコンクリート，鉄筋等の材料構成則及びそ の時点までの各微小要素のひずみ履歴に応じて決定され る.

\section{(2) 材料の構成則}

コンクリートの構成則は道路橋示方書4)に準抛する(図18）。かぶり部とコア部を別々にモデル化し，それぞれ の横拘束効果に応じた構成則を定義する. 鉄筋の構成則 はバイリニアでモデル化し（図-19(a)），BFRPロッド は破断に達するまで弾性部材にモデル化する（図19(b)）。なお，コンクリートの圧縮強度，鉄筋の降伏 強度および弾性係数，BFRPロッドの破断強度および弾 性係数については材料試験の実測值を使用し，それ以外 の諸元についてはコンクリート標準示方書 ${ }^{20)}$ 上り算出す る（表-2）。

\section{（3） 解析モデル}

本解析モデルの概要を図-20に示す，載荷方法は，実 験と同様のサイクルで変位制御とする. ファイバーモデ ルは，平面保持の仮定のもと，物性の一軸特性で評価す

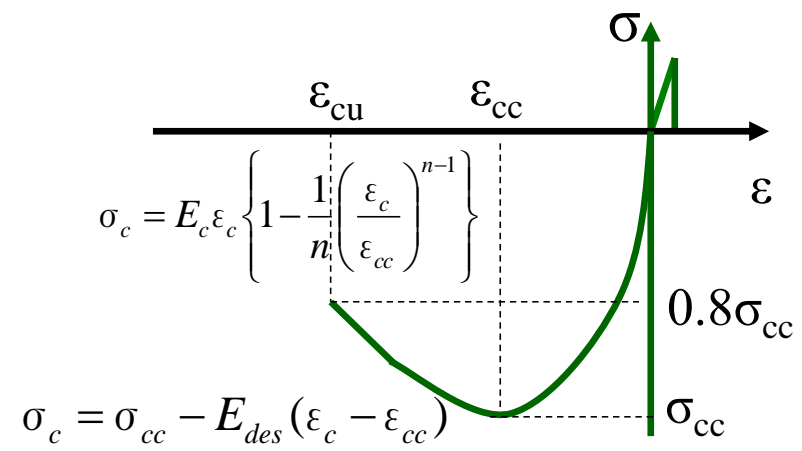

図-18 コンクリートの応力ーひずみ関係 


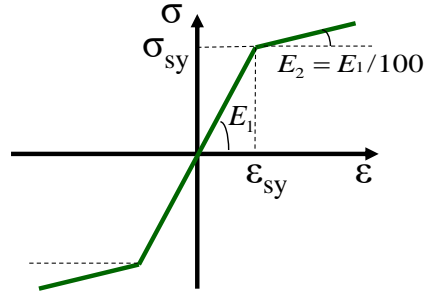

(a) 鉄筋

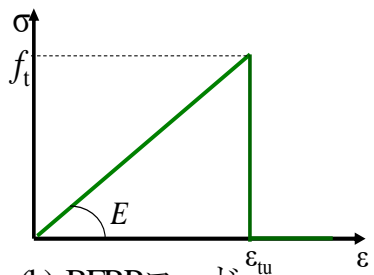

(b) BFRPロッド
図-19 鉄筋の応力ーひずみ関係
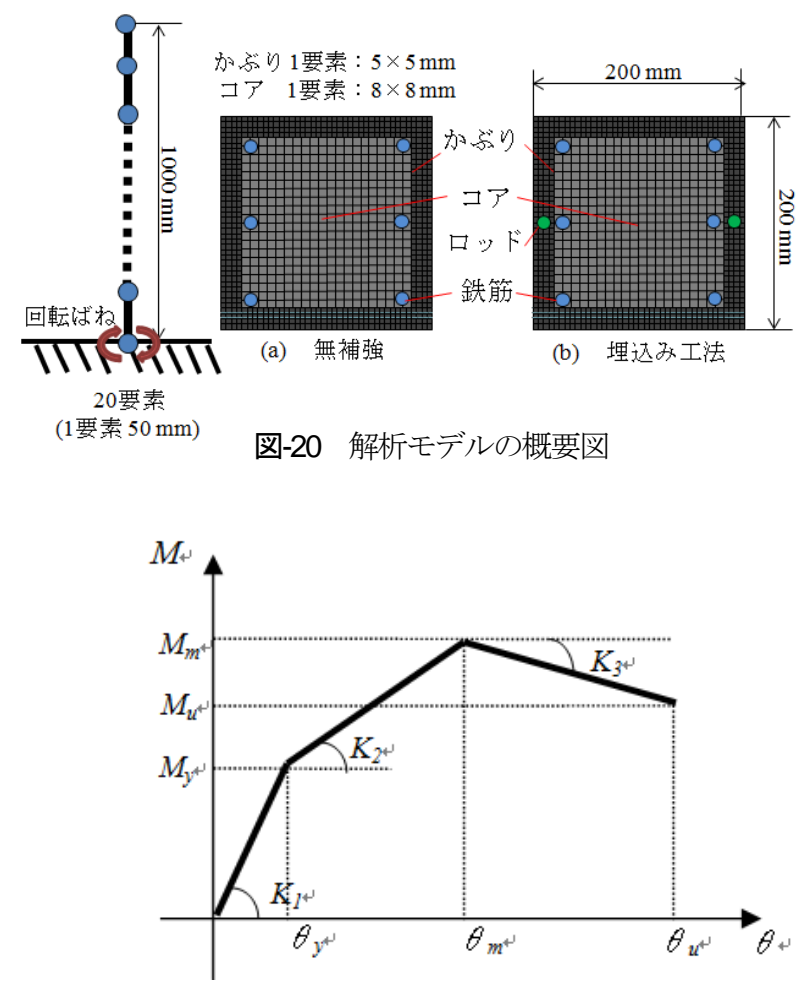

図-21 トリリニア型M- $\theta$ モデル

るため, 材料間の付着評価は不可能である. そのため, 基部に付着すべりをモデル化した非線形回転バネを直列 結合で導入し，それぞれのバネ值は実験で得られたP- $\delta$ 関係の初期勾配が解析結果と一致するように設定した ${ }^{21)}$. 付着滑りモデルは，鉄筋降伏前の第1段階，二次剛性を 示し付着滑りが顕著に表れない第2段階，付着すべりに よる変形が著しく表れる第3段階としてトリリニア（図21）で評価した．コンクリート標準示方書20)では，鉄筋 の抜け出し量を鉄筋径の指数関数で評価している. その ため, 本試験においても回転ばねのパラメータは, D10 D14の実験体（RC2-D10-E，RC2-D10-EP，RC2-D12-E， RC2-D12-EP， RC2-D14-E，RC2-D14-EP）6体の結果より 指数近似で算出した.

$$
\begin{aligned}
& K_{1}=19731 e^{0.1444 D} \\
& K_{2}=\left\{\begin{array}{l}
135 e^{0.389 D} \\
11 e^{0.5443 D}
\end{array}\right.
\end{aligned}
$$

$$
\begin{aligned}
& K_{3}= \begin{cases}8 e^{0.4005 D} & \text { (E接着) } \\
0 & \text { (EP接着) }\end{cases} \\
& M_{y}=\left\{\begin{array}{l}
1.2431 e^{-0.026 D} M_{\max } \\
1.1826 e^{-0.028 D} M_{\max }
\end{array}\right. \\
& \text { ここに, }
\end{aligned}
$$

$\mathrm{K}_{1}, \mathrm{~K}_{2}, \mathrm{~K}_{3}$ ，図-21に示すばね係数 $(\mathrm{kN} \cdot \mathrm{mrad})$

$\mathrm{M}_{\max }$ ：ロッド破断時の曲げモーメント $(\mathrm{kN} \cdot \mathrm{m})$

$\mathrm{M}_{\mathrm{y}}$ : 鉄筋降伏時の曲げモーメント $(\mathrm{kN} \cdot \mathrm{m})$

\section{（4）比較}

実測值および解析值の荷重一变位関係を図-22, 図-23 にそれぞれ示寸．本工法適用供試体では，D12，D14に おいて鉄筋降伏時で天端の水平変位でそれぞれ $36 \%$, 30\%が抜け出しによる変位であったことより, 鉄筋およ びBFRPロッドの抜け出しを十分に評価する必要がある. 実験結果より算出した抜け出し量を回転ばねで再現し た解析では，D12-E，D12-EP，D14-E，D14-EP（表-1の RC2-D12-E，RC2-D12-EP， RC2-D14-E，RC2-D14-EPに相 当）でそれぞれ最大荷重誤差が7.5，7.5，8.8，9.9\%であ った，回転バネの傾きを示すば係数Kは，各段階で増 加傾向を示すことより, 破壊が進むにつれ, すべり量が 増加することを示している，また，す心゙ての段階でロッ ド径の増大でば称数Kが大きくなる傾向を示している ことから，付着すべり量はロッド径の増大で減少傾向に あると考えられる. また, すべての解析結果で, 実験の 最大荷重より小さな值を示した.

本工法では, 鉄筋降伏荷重および終局荷重は, 補強口 ッド径が大きくなるにつれ，増加傾向を示し，D14で最 大鉄筋降伏荷重で4\%，終局荷重で35\%の増加がみられ た。本工法は，ひび割れ抑制効果は見込めず，また， BFRPは鉄筋の弾性係数の1/4倍程度と低弹性を有する材 料であることから, 鉄筋降伏以前の段階では構造物の剛 性向上および鉄筋の応力負担効果は低く，補強効果が見 込めない，一方，鉄筋降伏以降は，BFRPロッドが応力 を十分に受け持つことで，二次剛性が発揮し，最大荷重 およびじん性の向上につながった.

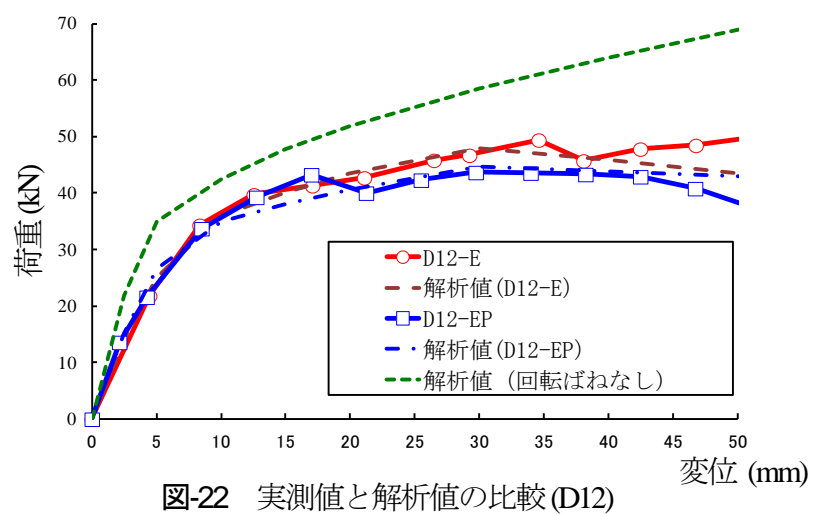

図-22 実測值と解析值の比較 (D12) 9)

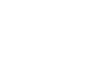




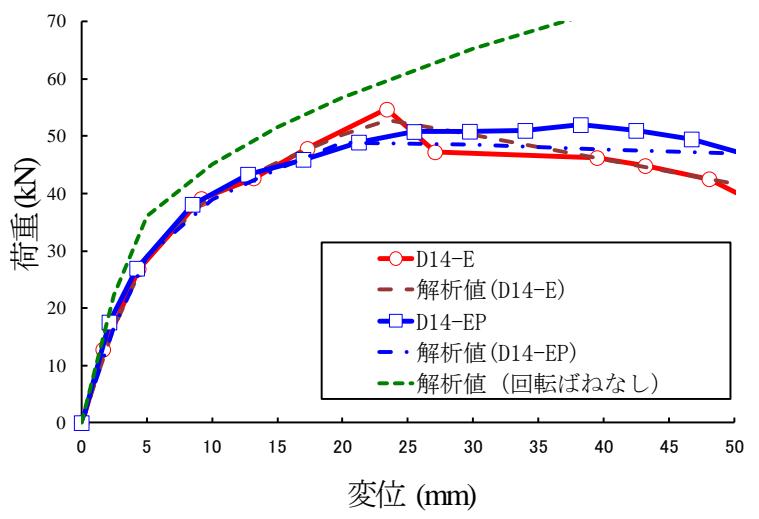

図-23 実測值と解析値の比較 (D14)

\section{8. 結論}

本研究では， RC橋脚の耐力およびじん性の向上を目 的とし，BFRPロッド埋め込み工法（NSM-BFRPR工法） を導入した構造を提案した。また， RC橋脚の而震補強 に対して，BFRP材が高性能な新素材としての有用性は 確認された。本工法を適用したRC橋脚の正負交番載荷 実験により得られた知見を以下に示す.

(1) 曲げ破壊型RC1シリーズ供試体および曲げせん断破 壊型RC2シリーズ供試体は，ともにBFRPロッドによる 埋め込み工法（NSM-BFRPR工法）を導入することでRC 橋脚に二次剛性の発揮による耐力向上を示した.

(2) RC1シリーズでは，鉄筋の降伏後，塑性域まで損傷 を与えても，鉄筋の座屈が生じていなければ，従来の $\mathrm{RC}$ 橋脚に比べて補強効果を得ることことを示した.

(3) 本工法では，鉄筋降伏後にBFRPロッドの材料特性に より二次剛性が発揮することで最大荷重が増加し，残留 変位の低減を確認した。

(4) BFRPロッドの埋設にエポキシパテおよびポリマーセ メントを併用することで，ロッドと柱間の付着を安定し て切らせることが可能となり，構造物のじん性を向上し た.

(5) 解析では，得られた実験結果より付着すべりモデル を作成し，4供試体で最大荷重誤差10\%内で再現するこ とができた．なお，本工法では，柱基部および柱側面部 からの付着剥離が進展するため, 今後両者の付着剥離に 着目する必要がある。

謝辞：本研究を行うにあたり，茨城大学工学部都市シ ステム工学科構造・地震工学研究室の関係各位からご協 力をいただいた．また，猪股大祐君および山田優樹君よ り載荷実験およびデータ整理の協力を得たことをここに 記して謝意を表する.

\section{参考文献}

1）（財）阪神高速道路管理技術センター（編）：大震災か ら学ぶ都市高速道路における地震対策一震災復旧から而
震補強，防災計画まで一，電気書院，2005年11月．

2) Kawashima,K.: Seismic design and retrofit of bridges, Proc.of 12th WorldConference on Earthquake Engineering, CD-ROM, No.2828, Auckland,New Zealand, 2000.

3) 土木学会阪神・淡路大震災調查報告編集委員会（編）： 阪神・淡路大震災調査報告土木構造物の応急復旧，補修， 補強，丸善， 1999.

4)（社）日本道路協会 : 道路橋示方書・同解説 $V$ 而震設計 編, 2002.

5) Ikeda,S.: Seismic behavior of reinforced concrete columns and improvementby vertical prestressing, Challenges for Concrete in the Next Millennium, Proc. Of XIIIth FIP Congress, Vol. 1, pp.879-884, Balkema Rotterdam,Netherlands, 1998.

6) 睦好宏史，Wael A. Zatar，牧剛史 : プレストレスを導入し た鉄筋コンクリート橋脚の而震性状，土木学会論文集， No.669/N-50, pp.27-38, 2001.

7)（社）プレストレストコンクリート技術協会 : プレスト レストコンクリート橋脚の耐震設計ガイドライン， 1999

8) 堺淳一, Stephen A.MAHIN, HyungilJEONG : 振動台加震実 験による残留変位低減型RC 橋脚の地震応答特性の評価, 土木学会論文集A，Vol.62 No.4，pp.713-728，2006.10.

9) 家村浩和, 高橋良和, 曽我部直樹 : アンボンド芯材を活 用した高耐震性能RC 構造の開発，土木学会論文集， No.710/-60, pp.283-296, 2002.

10) 細谷学 : 炭素䋊維シートを用いた鉄筋コンクリート橋脚 の而震補強設計法に関する研究，博士論文，東京工業大 学, 2002.

11）（社）日本道路協会 : 既設道路橋の而震補強に関する参 考資料，平成9年 8 月.

12)連続繊維補強コンクリート研究委員会 : 既続繊維補強コ ンクリート研究委員会報告書, 日本コンクリート工学協 会, pp.96-103, 1997.7.

13)連続繊維補強コンクリート研究委員会 : 既続繊維補強コ ンクリート研究委員会報告書（II），日本コンクリート 工学協会, pp.47-51，1998.5.

14）呉智深，岩下健太郎，棌暁荷，小林朗 : FRP ケーブルの 埋め込み緊張補強技術の確立，構造工学論文集，Vol.56A pp.630-643, 2010.3.

15) Fahmy, M.F.M., Wu, Z.S., Wu, G. : Post-earthquake recoverability of existing RC bridge piers with FRP composites. Construction and Building Material 24, pp.980-998, 2010.

16) Fahmy, M.F.M. : Enhancing recoverability and controllability ofreinforced concrete bridge frame columns using FRP composites，博士論 文，茨城大学， 2010 .

17) 猪八重由之，武若耕司：各種FRPロッドの耐久性に関す る実験的検討，コンクリート工学年次論文報告集，Vol.16， No.1, 1997.7.

18）独立行政法人土木研究所而震研究グループ而震チーム： 橋の耐震性能の評価に活用する実験に関するガイドライ 
ン（案）（橋脚の正負交番載荷実験方法及び振動台実験 方法），土木研究所資料，第4023号，2006年8月.

19）吉川弘道 : 鉄筋コンクリートの解析と設計 一限界状態設 計法と性能設計法一, pp.93-96, 丸善株式会社, 2004.

20) 社団法人土木学会コンクリート委員会 : コンクリート標 準示方書[設計編], pp.84-85, 丸善株式会社, 2007.
21）右近八郎, 幸左賢二, 井上晋, 吉澤義夫 : RC標準橋脚の ファイバーモデルによる交番載荷実験シミュレーション 解析，コンクリート工学年次論文報告集, Vol.17, No.2, 1995.

\section{EXPERIMENTAL STUDY ON REINFORCED CONCRETE BRIDGE PIERS STRENGTHENED WITH NEAR SURFACE MOUNTED BFRP RODS}

\section{Zhishen WU, Jien LIN, Huang HUANG, Shinya KAI and Kouta INOUE}

Resilience and recoverability play important roles in controlling the structural performance of reinforced concrete (RC) structures after seismic actions. The main objective of this paper was to propose a new earthquake resistant method using a near surface mounted basalt fiber reinforced polymer rods (BFRPR-NSM) to minimize residual displacements, and to execute a fiber model based simulation evaluating the structural performance of the proposed BFRPR-NSM method reinforced RC columns. Based on the experimental results on both existing RC bridge columns and newly constructed columns, the beneficial effects of the BFRPR-NSM method were discussed. Moreover, the analytical studies on post-yield stiffness and residual deformations of BFRPR-NSM reinforced columns were conducted. Finally, suitable FRP design assumptions and concepts certifying the reality of post-yield stiffness are given. 